Jurnal Scripta Teologi dan Pelayanan Kontekstual
ISSN 2086-5368 (Print)
ISSN
Http://ejournal.stte.ac.id
Vol.1, No.1, pp. 158-181, 2017

\title{
Pastoral Konseling Terhadap Anak Usia 5-12 Tahun Yang Mengalami Krisis Kasih Sayang
}

\begin{tabular}{l} 
STT \\
\hline INFO ARTIKEL \\
\hline Sejarah Artikel: \\
Diterima : 05 Okt 2017 \\
Direvisi : 12 Okt 2017 \\
Disetujui: 19 Okt 2017 \\
Dipublikasi: 28 Okt \\
2017
\end{tabular}

Kata Kunci:

Pastoral,Konseling,

Pelayanan,

Kontekstual

Keywords:

keyword one, keyword two, keyword three.

\section{Suharta}

STT Ebenhaezer Tanjung Enim, Imsiharta.te@gmail.com

\section{ABSTRAK}

Anak-anak di dunia ini sangat membutuhkan bimbingan dari orang tua yang dilakukan dengan adanya rasa kasih sayang dari keluarga terutama bimbingan dari orang tua. Dengan bimbingan dan kasih sayang yang sepatutnya, seorang anak akan bertumbuh menjadi suatu kesukaan bagi orang tua, berkat bagi dunia, dan terang bercahaya bagi Allah. Pengaruh keluarga atau pun juga guru yang mengajar mereka di sekolah bagi perkembangan anak sangatlah besar. Karena guru juga merupakan tempat utama bagi pembentukan karakter, watak, dan kepribadian anak di sekolah. Dengan bantuan dan dorongan dari keluarga, teman-teman, dan anggota-anggota keluarga besar, anakanak seharusnya merasakan masa kanak-kanak sebagai suatu masa untuk menemukan pribadi seperti yang telah dikehendaki oleh Tuhan. Namun keadaan dunia ini tidaklah selalu sesuai dengan yang diharapkan. Dunia saat ini memberikan kepada anak-anak kemudahankemudahan untuk melakukan sesuatu yang tidak sesuai dengan yang diajarkan dalam keluarga begitu juga dengan lingkungan sangat mempengaruhi pembentukan pola-pola kepribadian maupun pola-pola sikapnya. Ketika orang tua tidak memberikan kasih sayang kepada anak sejak kecil yang seharusnya diterima oleh anak dan ketika orang tua gagal memberikan kasih sayang kepada anak, maka anak tidak dapat bertumbuh dengan baik dan di sekolah pun anak tidak aktif dalam mengikuti pengajaran. Hal yang lainnya ialah, mereka bertumbuh menjadi anak-anak yang pemalu dan takut untuk tampil didepan umum, juga kurang percaya diri, menganggap diri kurang mampu, tidak hanya di sekolah namun di lingkungan juga. Peristiwa lainnya ialah ketika orang tua tidak terlalu mementingkan pertumbuhan anak, maka akan membuat anak sulit mengikuti pengajaran yang baik di sekolah. Kasus-kasus di atas, adalah akibat kurangnya pastoral konseling terhadap anak pada usia 5-12 tahun sehingga berdampak pembentukan karakter dan emosi yang kurang baik. 
Oleh sebab itu guru diharapkan mampu untuk mengerti pastoral konseling dengan benar dan menjalankannya didalam pengajaran tiaptiap hari yang dilakukan seorang guru di sekolah, karena pastoral konseling terhadap anak yang benar akan mempengaruhi kecerdasan anak dan anak dapat merasakan kasih sayang atau perhatian yang seharusnya mereka dapatkan dari orang tua.

\begin{abstract}
Children in this world really need guidance from parents which is done with the love of family, especially guidance from parents. With proper guidance and affection, a child will grow into a joy for parents, a blessing to the world, and a bright light for God. The influence of the family or also the teacher who teaches them at school for children's development is very large. Because the teacher is also the main place for the formation of character, character, and personality of children in school. With the help and encouragement from family, friends, and members of extended families, children should feel childhood as a time to find the person who is desired by God. But the state of this world is not always as expected. Today's world gives children the ease of doing things that are not in accordance with what is taught in the family as well as the environment greatly influencing the formation of personality patterns and patterns of attitude. When parents do not give love to children since childhood which should be accepted by children and when parents fail to give love to children, then the child cannot grow properly and even in school the child is not active in following teaching. The other thing is, they grow up to be shy children who are afraid to appear in public, also lack of confidence, consider themselves less capable, not only in school but also in the environment. Other events are when parents are not too concerned with the child's growth, it will make it difficult for children to follow good teaching in school. The cases above, are due to the lack of pastoral counseling of children at the age of 5-12 years, which results in the formation of character and emotions that are not good. Therefore teachers are expected to be able to understand pastoral counseling correctly and carry it out in teaching every day that is done by a teacher at school, because pastoral counseling to the right child will affect the intelligence of children and children can feel the love or attention they should get from parents.
\end{abstract}

\title{
Pendahuluan
}

Pembimbingan kerohanian melalui pelayanan pastoral konseling merupakan suatu hal yang sangat penting bagi pembentukan dan pertumbuhan kerohanian anak, karena akan berpengaruh besar bagi perkembangan dari cara berfikir, dan tingkah laku anak. Hasil pelayanan pastoral konseling dalam pembimbingan kerohanian akan terus terlihat pada sifat dan sikap anak. Melalui pembimbingan kerohanian diharapkan anak dapat memiliki kepribadian dan karakter anak yang baik. 
Istilah pastoral dalam Bahasa Indonesia Kontemporer diterjemahkan sebagai gembala. Oleh sebab itu, pelayanan pastoral disebut sebagai "penggembalaan" yang merupakan ekspresi dari penjagaan atau pemeliharaan Allah yang penuh kasih. Jadi, pastoral adalah suatu pelayanan yang dilakukan oleh seorang gembala atau pastor dan bisa saja disebut sebagai guru pengajar bagi anak-anak. Dan tugas seorang guru dapat membimbing dan mendidik anak-anak pada pengajaran Firman Tuhan dan supaya anak-anak dapat bertumbuh menjadi anak yang takut Tuhan.

Dalam pembimbingan Kristen sisi kerohanian seseorang menjadi fokus utama. Menurut Anton M. Moeliono, kerohanian berasal dari kata rohani yang berarti roh, perihal rohani dan kerohanian ialah sifat-sifat rohani. Peter Salim dan Yenny Salim juga menuliskan dalam bukunya menuliskan bahwa kerohanian berasal dari kata rohani yaitu roh, berupa roh, dan yang berhubungan dengan roh. Berbicara tentang roh ada beberapa hal yang dapat dijabarkan antara lain: yaitu pertama, batin adalah sesuatu hal yang dapat didalam hati. Kedua, spiritual adalah berbicara tentang mental dan moral seseorang. Ketiga, kejiwaan adalah berbicara tentang kebatinan dan kerohanian seseotang. Sedangkan kerohanian berbicara tentang sifat-sifat rohani atau tentang hal-hal rohani. Jadi kerohanian adalah keadaan seseorang yang berhubungan dengan roh dimana didalamnya berbicara tentang batin, spiritual, dan kejiwaan seseorang.

Hal ini menunjukkan bahwa pelayanan pastoral konseling melalui pembimbingan kerohanin yang diberikan guru yang mengajar bagi anak-anak disekolah Sukacita. Pastoral konseling merupakan cara yang harus dipakai oleh guru untuk menuntun orang yang dilayani atau yang dibimbing dapat menyelesaikan masalahnya dengan baik. Oleh sebab itu dalam pastoral konseling bagi guru peranannya sangta penting, karena guru atau hamba Tuhan menjadi mediator yang tepat dalam menjangkau anakanak. Dimana tugas seorang guru atau hamba Tuhan menjadi seorang konselor yang baik bagi konselinya. Konselor secara aktif terlihat dalam proses membantu klien memusatkan perhatian masalah-masalahnya dan mencari pemecahan untuk masalahmasalah tersebut.

Dengan demikian orang tua pun memiliki tugas dan tanggungjawab yang besar Anak-anak yang dibimbingnya. Hal ini harus terlihat dalam tindakan yang nyata yaitu mengasihi, melindungi, mendidik, membimbing, dan mendisiplin anak-anak mereka. Dalam kitab Mazmur 127:4 tertulis "seperti anak-anak panah di tangan pahlawan, demikianlah anak-anak pada masa muda”. Firman Tuhan ini mengibaratkan anak-anak seperti anak panah di tangan pahlawan yang oleh pahlawan akan diarahkan kesasaran yang tepat. Oleh sebab itu betapa penting dan berartinya peranan orang tua dalam pembimbingan kerohanian, terkhusus bagi anak-anak yang mengalami krisis kasih sayang. Hal ini dikarenakan anak yang mengalami krisis kasih sayang memiliki kompetensi yang sama dengan anak-anak pada umumnya dalam mencapai keberhasilan dimasa depannya.

Pengaruh keluarga atau guru yang mengajar disekolah perkembangan anak sangat besar. Karena guru adalah tempat utama bagi pembentukan karakter, watak, dan kepribadian anak disekolah. Dengan bantuan dan dorongan dari keluarga, temanteman, dan anggota-anggota keluarga besar, anak-anak seharusnya merasakan masa kanak-kanak sebagai suatu masa untuk menemukan pribadi seperti yang telah dikehendaki oleh Tuhan. Phillips Kilbourn menyatakan bahwa Allah telah merencanakan masa kanak-kanak sebagai sebagai suatu masa khusus untuk memelihara bakat-bakat serta kemampuan-kemampuan yang diberikan Allah kepada 
mereka. Tentunya setiap orang tua harus dapat memikirkan pola yang baik untuk mendidik anak-anaknya agar anak-anaknya menjadi pribadi yang dikehendaki oleh Tuhan. Tentang hal ini, Bagus Suryantoro menuliskan:

Melalui pendidikan yang benar dari orang tua, maka anak dapat merasakan nikmatnya kehidupan menjadi "manusia sepenuhnya", atau sebaliknya anak akan menjadi "makhluk yang tercabik" tanpa sempat menjadi manusia Tuhan yang seharusnya akibat kegagalan orang tua yang tidak memberikan "yang terbaik dari Tuhan" untuk anak-anaknya.

Tentunya pendidikan dari keluarga yang takut akan Tuhan akan memberikan pengaruh yang baik dan benar bagi perkembangan seorang anak. Itu berarti takut akan Tuhan adalah modal untuk membimbing seorang anak dengan benar, orang yang takut akan Tuhan akan mempertanggungjawabkan semua tindakannya kepada Tuhan. Hal ini harus menjadi perhatian penuh bagi setiap orang yang mau mendidik anak agar anak-anak tidak dibawa pada tujuan yang dapat merusak hidup mereka.

\section{Metode Penelitian}

Dalam penulisan ini penulis menggunakan metode deskriftif-bibliologis. Metode deskriftif adalah suatu metode pentlitian yang meneliti sekelompok manusia, suatu objek, suatu kondisi, suatu system pemikiran ataupun suatu kilas peristiwa masa sekarang. Adapun tujuan penelitian ini adalh membuat deskripsi, gambaran atau lukisan secara sistematis, factual dan akurat mengenai fakta-fakta, sifat-sifat serta hubungan antar fenomena yang diteliti.

Pengumpulan data yang dilakukan dengan cara penelitian menanalisis literatur dan penelaan dokomen.

\section{Hasil Dan Pembahasan}

\section{A. Pengertian Pastoral Konseling}

Pastoral konseling adalah sebuah proses pelayanan untuk menolong yang dilakukan oleh konselor kepada konseli. Konselor adalah pihak yang memberikan pertolongan. Sedangkan konseli adalah sebagai orang yang ditolong sering tidak mampu melihat persoalannya dengan jernih. Bersamaan dengan itu, Yakub B. Susabda dalam bukunya memberikan pengertian pastoral konseling adalah sebagai berikut:

Konseling pastoral adalah hubungan timbal balik antara hamba Tuhan sebagai konselor dengan konselinya. Konselor membimbing konseli kedalam suatu suasana percakapan konseling yang ideal, yang memungkinkan konseli betulbetul mengerti apa yang sedang terjadi pada dirinya sehingga ia mampu melihat tujuan hidupnya itu dengan kekuatan dan kemampuan dari Tuhan.

Berdasarkan definisi tersebut, Yakub B. Susabda menjelaskan paling tidak ada empat (4) aspek penting yang harus dikenal oleh setiap konselor (hamba Tuhan) yaitu: pertama, Hubungan timbal-balik (Interpersonal relansionship) antara konselor dengan konselinya. Kedua, hamba Tuhan sebagai konselor. Ketiga, suasana percakapan konseling yang ideal (condusive atmosphere). Keempat, melihat tujuan hidupnya dalam relasi dan tanggung jawabnya pada Tuhan dan mencapai tujuan itu dengan takaran, kekuatan dan kemampuan seperti yang sudah diberikan Tuhan padanya. Lebih luas lagi Tulus Tu'u menjelaskan mengenai pastoral konseling sebagai berikut yaitu: 
Pastoral konseling adalah pelayanan yang dilakukan oleh gereja dengan melawat dan mencari satu persatu jemaat yang sedang bergumul dalam hidupnya. Pencarian dan pelawatan itu dilakukan untuk menolong mereka melalui suatu percakapan yang interaktif, timbal-balik, dan mendalam. Melalui percakapan itu, konselor dapat mendamping, membimbing, dan mengarahkan konseli untuk menemukan solusi.

Dengan demikian, pengertian pastoral konseling adalah merupakan suatu cara yang dilakukan oleh seorang konselor kepada konseli dalam pelayanan yang bersifat rohani, karena pelayanan pelayanan pastoral merupakan pelayanan yang memberikan pertolongan kepada kepda manusia yang mengalami masalah sampai memperoleh solusi yang tepat yang didasari pada Alkitab sebagai Firman Tuhan. Pastoral konseling juga dapat memberikan nasihat, penghiburan dan penguatan bagi warga gereja.

\section{B. Pastoral Konseling Dalam Alkitab}

Keterlibatan seorang hamba Tuhan dalam pelayanan pastoral konseling merupakan hal yang tidak dapat dihindari. Misalnya ketika seorang jemaat datang menghampiri seorang pendeta dan berbicara kepada pendeta tentang masalah yang di hadapi dan kerohaniannya, maka saat itu pelayanan konseling sedang dilakukan. Namun banyak pendeta yang sering kali tidak peka atau tidak dapat mempergunakan waktu seperti ini dengan baik, bahkan ada yang tidak mengetahui dengan jelas apa pelayanan pastoral konseling itu dengan baik dan benar.

Pastoral konseling merupakan salah satu wahana yang istimewa untuk mendemontrasikan kebenaran. Bersama dengan itu, Howard Clinebell menuliskan bahwa Tuhan Yesus Kristus adalah sumber dari kebenaran itu, maka kebenarankebenaran yang berasal dari Allah (baik yang dinyatakan melalui dan didalam Alkitab maupun diluar Alkitab) seharusnya tidak bertentangan dengan yang lainnya. Alkitablah sebagai tolak ukur dalam pelayanan pastoral konseling untuk memberikan tuntutan, arahan bagi pelayan Tuhan dalam melaksanakan pelayanan.

Pastoral konseling selalu melibatkan Alkitab dan Roh kudus bagi semua pelayanan pastoral baik berupa pemberitaan Injil, pengajaran dan pelayanan konseling. Pelayanan pastoral merupakan salah satu bentuk pelayanan gereja yang amat baik. Pelayanan ini pada dasarnya merupakan pelayanan gereja yang mencerminkan pemeliharaan Allah terhadap ciptaan-Nya, secara khusus terhadap manusia. Pemeliharaan ini, didalam Alkitab digambarkan seperti pemeliharaan yang dilakukan gembala terhadap domba-domba-Nya.

Oleh sebab itu, hamba Tuhan sebagai konselor harus memiliki dasar yang menjadi pegangan dalam pelayanan pastoral konseling. Adapun dasar mutlak yang harus menjadi pegangan dalam hidup seorang konselor yaitu Alkitab dan Roh kudus yang merupakan tolak ukur di dalam pelayanan pastoral konseling. Dalam uraian berikut ini penulis akan memaparkan tentang dasar pelayanan dari pastoral konseling dalam Perjanjian Lama dan Perjanjian Baru.

\section{Perjanjian Lama}

Istilah yang dipakai dalam Perjanjian Lama menunjuk kepada Allah sebagai gembala umat-Nya. Kata "Konseling" dalam Perjanjian Lama berasal dari bahasa Ibrani "Ya'ats" dalam bentuk kata kerja, yang berarti advice, counsel, purpose, plan . Artinya memberi nasihat atau memperingatkan, membimbing, memberikan tujuan, 
merencanakan. Kata "Ya'ats" juga ditemukan dalam berita Mesianik, yaitu Yesaya 9:6 "Besar kekuasaannya, dan damai sejahtera tidak akan berkesudahan di atas takhta Daud di dalam kerajaannya, karena ia mendasarkan dan mengokohkannya dengan keadilan dan kebenaran dari sekarang sampai selama-lamanya", dimana pengertian dari kata "Konselor" menunjuk kepada Mesias sebagai Raja yang menetapkan membawa program dan rencana-Nya yang akan membuat dunia menjadi baik. Allah telah memberikan teladan dalam pelayanan pastoral konseling dimana Allah sendiri merupakan pemberi nasihat yang baik bagi domba-domba-Nya.

Tulus Tu'u, dalam bukunya menjelaskan tentang “dasar-dasar konseling pastoral” yang menuliskan tugas seorang gembala yang telah dilakukan oleh Allah sebagai gembala yang baik yaitu:

Pertama, tugas konseling pastoral merupakan tugas dan kepercayaan dari Tuhan sendiri. Bila tugas itu dilalaikan, Tuhan dapat mempercayakan tugas ini pada pihak lain. Boleh jadi, domba-domba itu akan dikirik atau diberikan kepada gembala-gembala yang lain, yang mau melayani mereka. Kedua, sekarang banyak domba Tuhan yang terlantar, kurang diperhatikan, dan bergulat sendiri untuk mengatasi pergumulannya. Kita diingatkan untuk memperhatikan kelompok yang terpinggirkan dalam jemaat ini. Ketiga, jika tidak diperhatikan, domba-domba yang bergumul dengan beratnya problem ini akan terancam dan menjad mangsa berbagai roh-roh di dunia. Kita bersalah bila berdiam diri. Jadi, pelayanan pastoral konseling sangatlah penting dilaksanakan untuk menolong mereka.

Oleh karena itu, dalam Perjanjian Lama istilah gembala sering sekali dipakai untuk menggambarkan Allah sebagai gembala yang setia menggembalakan seperti merawat, menjaga, memelihara dan mengawasi domba-domba-Nya.

\section{Perjanjian Baru}

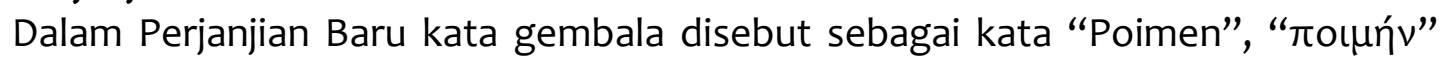
kata ini muncul 18 kali dan kata ini sering disebut didalam kitab Injil. Dalam Perjanjian Baru, kata konseling diterjemahkan dengan kata "Bouleuo" yang memiliki beberapa pengertian yaitu: Purpose, counsel, resulation, decision. Yang artinya adalah tujuan, nasehat, resolusi, keputusan. Dasar pastoral konseling menurut Perjanjian Baru yang terambil dari Surat Yohanes 10, dimana Kristus sebagai gembala Agung.

Dalam perjalanannya selama melayani didunia, Yesus Kristus tampil dalam 4 (empat) karya yaitu: pertama, Yesus tampil sebagai guru. Kedua, Yesus tampil sebagai pembebas. Ketiga, Yesus tampil sebagai penyembuh. Keempat, Yesus tampil sebagai gembala. Yesus berjuang untuk membela domba-Nya, dan rela memberikan hidup-Nya, sebab la begitu mengasihi dan mengenali satu persatu domba-domba-Nya. Keadaan ini berbeda dengan gembala upahan, ketika musuh datang gembala upahan akan melarikan diri dari dombanya dan menyelamatkan dirinya sendiri saja, itu bisa dilihat dari (Yohanes 10:12,13). Lebih lanjut Tulus Tu'u menjelaskan tentang pelayanan pastoral konseling bukanlah suatu pelayanan upahan. Jika kita melihat hasil pelayanan hanya dengan upah, kita menempatkan diri sebagai pekerja upahan. Sebagai konselor yang melayani domba milik Kristus, harus memiliki jiwa yang rela berkorban dan dapat mengenal dombanya. Dengan demikian, seorang pastor atau seorang gembala harus memiliki tanggung jawab untuk memelihara, menjaga, dan memimpin domba yang di gembalakan seperti Kristus sendiri yang telah setia menggembalakan domba-domba- 
Nya. Yesus Kristus adalah gembala Agung yang telah menjadi teladan bagi gembala jemaat dalam menggembalakan jemaat dan bagi seorang guru yang menggembalakan muridnya. Seorang pastor atau gembala merupakan orang yang dipanggil dan ditetapkan untuk memelihara dan dapat menjaga umat-Nya

\section{Dasar Alkitabiah Pastoral Konseling Terhadap Anak Usia 5-12 Tahun Yang Mengalami Krisis Kasih Sayang}

Alkitab adalah Firman Tuhan, yaitu perkataan-perkataan Allah yang ditulis oleh manusia yang dipakai-Nya dan diberi wahyu untuk menuliskan setiap perkataan itu. Firman Allah adalah kebenaran mutlak dan standar kebenaran. Segala sesuatu harus dinilai benar atau salah berdasarkan standar kebenaran yaitu Alkitab. Alkitab adalah Firman Allah yang berisi peraturan, pengajaran, dan kisah-kisah yang memberi pelajaran dan menginspirasi para pembacanya. Alkitab bukan hanya standar buku, namun Alkitab berkuasa karena Alkitab adalah perkataan-perkataan Allah. Pada bagian ini penulis akan menjelaskan tentang dasar Alkitabiah pastoral konseling terhadap anak usia 5-12 tahun yang mengalami krisis kasih sayang yang terbagi didalam kasih, adil, lemah lembut.

\section{Kasih (Galatia 2:20)}

Kasih adalah dasar hidup di dalam keluarga. Kasih merupakan landasan dalam membangun dalam keluarga. Tanpa kasih sebagai dasar, maka semua teknik dan keahlian dalam hidup berkeluarga akan gagal.

Kasih adalah suatu sikap yang dinyatakan dalam sesuatu yang konkrit, di dalam suatu wujud yang nyata, seperti yang dituliskan oleh Paulus yang menggambarkan kasih Allah kepada jemaat, dalam surat Efesus 5:25; Galatia 2:20. Alkitab menjelaskan bahwa kasih adalah hukum yang terutama dan yang paling utama. Hal ini dikatakan oleh Yesus dan ditulis oleh Matius dalam Injilnya. Kasih bukanlah sesuatu yang abstrak, namun kasih dapat terlihat dan di buktikan melalui tindakan yang ditunjukkan.

Anak-anak juga membutuhkan kasih sayang mereka yang didapat dari orang tua. Kadang-kadang mereka bersikap seolah-olah tidak membutuhkannya, tetapi sebenarnya mereka membutuhkannya. Jangan sampai kasih sayang anak-anak menjadi kosong oleh karena tidak pernah diisi oleh orang tuanya setiap harinya. Orang tua harus mengetahui cara terbaik dalam menunjukkan kasih sayang kepada anak sesuai dengan situasi dan kondisi. Menunjukkan kasih kepada anak tidak selalu harus memberikan hadiah atau mengikuti semua kemauan anak. Seorang anak yang tidak pernah mendapat kasih sayang orang tua akan sulit menyatakan kasih sayang. Sekarang ini banyak keluarga lalai dalam melimpahkan kasih sayang atau perhatian dengan lain. Mereka lupa bahwa bila seorang anak tumbuh dalam lingkungan yang dingin, tanpa kasih sayang, dengan sendirinya anak akan mengalami banyak kesulitan dalam memberi dan menyatakan cinta mereka.

\section{Adil (Ulangan 6:4-9)}

Orang tua tidak boleh terjebak dalam kasih yang tidak seimbang. Maksudnya ialah orang tua tidak boleh membeda-bedakan anak mereka untuk alasan tertentu. Orang tua harus menyadari bahwa anak adalah anugerah Allah. Setiap anak memiliki keunikan atau karakter yang berbeda. Keberadaan anak harus dihargai sebaagi suatu 
pribadi. Anak-anak harus merasa bahwa dirinya berharga dan dicintai. Anak-anak juga harus diperlukan secara adil terhadap saudaranya.

Menjadi orang tua yang adil bukanlah hal yang mudah, tidak semua memahami hal ini. Namun dalam segala hal perbedaan yang mereka miliki, orang tua harus mengasihi dan menghargai masing-masing mereka dengan kasih dan penghargaan yang sama. Orang tua yang adil tidak berpihak hanya kepada anak yang satu dan mengabaikan anak yang lainnya. Memperlakukan anak yang satu dengan yang lain secara adil dan tidak berat sebelah.

Kesulitan muncul ketika anak berselisih antara satu dengan yang lainnya. Dalam hal ini orang tua tidak boleh memihak satu dan menyalahkan yang lain, melainkan orang tua harus menjadi guru damai yang bersedia mengalah untuk memulihkan dan persekutuan. Untuk menjadi orang tua yang adil, orang tua harus memahami sifat dan karakter masing-masing anak.

\section{Lemah Lembut (Efesus 6:4)}

Banyak orang tua berangapan bahwa mendidik anak dengan keras, akan menjadikan anak lebih baik. Pengalaman yang dilalui sejak kecil, banyak mempengaruhi kesehatan mental seseorang. Selain itu ada juga yang beranggapan bahwa mendidik anak dengan kekerasan itu baik dan perlu ditanamkan, agar nantinya anak dapat hidup sebagaimana mestinya. Memang banyak alasan yang menyebabkan orang tua menjadi keras, antara lain didorong oleh keinginan agar anaknya belajar hidup teratur dan disiplin, agar dewasa nanti anak dapat hidup dengan baik.

Namun perlu diketahui bahwa mendidik anak dengan keras akan menyebabkan gangguan terhadap ketegangan anak. Akibatnya anak kurang memiliki inisiatif spontanitas, tidak percaya pada diri sendiri, tidak sanggup mengeluarkan pendapat. Oleh sebab itu, orang tua perlu memperhatikan hal ini, yaitu mendidik dengan kekerasan tidak akan menyelesaikan persoalan, justru akan membuat keadaan lebih buruk. Orang tua harus bersikap lemah lembut dan penuh kasih sayang dalam mendidik anak. Bersikap lemah lembut bukan berarti tidak pernah marah atau menghukum anak. Orang tua yang bersikap lembut biasanya di buktikan dengan menyatakan kasih sayangnya secara terbuka dan cukup memberikan semangat kepada anaknya.

Salah satu keunggulan orang tua yang mampu untuk mendidik dengan kelemah lembutan adalah mampu berkomunikasi dengan anak. Orang tua yang lemah lembut mampu untuk bertindak tegas tanpa kekerasan. Lemah lembut juga bukan berarti tidak menghukum, namun orang tua yang lemah lembut akan menghukum tetapi juga mendidiknya agar tidak melakukan hal yang sama.

\section{Prinsip-Prinsip Pelayanan Pastoral Konseling}

Pelayanan pastoral konseling merupakan pelayanan yang dipercayai oleh Allah kepada setiap hamba Tuhan. Paul D. Mirer menjelaskan bahwa seorang hamba Tuhan merupakan wakil Allah untuk menolong persoalan ataupun pergumulan yang dihadapi oleh jemaat Tuhan. Konseling Kristen unik karena didasarkan pada kasih Allah, dan konseling Kristen mampu mengatasi masa lalu konseli dengan efektif. Keunikan pastoral konseling terletak pada sikap hamba Tuhan (konselor) yang percaya bahwa pelayanan ini adalah pelayanan yang dipercayakan oleh Allah sendiri kepadanya. Tanpa 
kepercayaan ini, hamba Tuhan akan cenderung untuk mempraktekkan pelayanan ini secara sekuler.

Selain itu pelayanan konseling bergantung pada kuasa Roh kudus. Scheunemann dalam bukunya yang berjudul "Apa kata Alkitab tentang dogma Kristen" mengemukakan bahwa: Roh kudus adalah Roh hikmat dan Roh pengertian (Yesaya 11:2). Dengan karunia hikmat-Nya (I Korintus 12:8), la bersedia dan siap untuk membuka Alkitab sambil membimbing manusia kedalam segala kebenaran-Nya. Selanjutnya, Yakub B. Susabda mengatakan, keunikan pastoral konseling juga terletak pada sikap hamba Tuhan yang percaya akan kehadiran, pengaruh dan campur tangan langsung dari Allah dalam pelayanan konseling. Pelayanan pastoral konseling didasarkan pada kebenaran Firman Allah. Keunikan pastoral konseling terletak pada sikap hamba Tuhan yang percaya bahwa Alkitab adalah Firman Allah yang tertulis karena itu standar kebenaran untuk menilai tingkah laku manusia adalah Alkitab. Karena Alkitab berkuasa terhadap hati manusia, dan Alkitab merupakan pusat hidup manusia secara mutlak. Scheunemann memaparkan dalam bukunya bahwa berdasarkan ilham Ilahi-Nya, maka Alkitab berkuasa atas segala sesuatu dan memiliki wibawa tertinggi.

Dengan demikian, hamba Tuhan sebagai wakil Allah dalam dunia ini untuk dapat membantu konseli yang ada dalam pergumulan hidup yang dihadapinya, dan meyakini bahwa pelayanan ini suatu pelayanan yang telah Allah percayakan kepadanya. Konselor dalam melakukan pelayanan pastoral konseling harus menyadari bahwa adanya peranan Roh kudus didalamnya untuk mengubahkan hati konseli serta yang menjadi landasan dalam melakukan pelayanan pastoral melalui Alkitab harus menjadi standar kebenaran yang mutlak.

\section{Mendidik Berdasarkan Firman Tuhan}

Firman Allah adalah dasar hidup dari orang percaya. Firman Allah juga kaya akan pengajaran-pengajaran yang mendidik setiap pembacanya. Demikian halnya anak-anak harus dididik berdasarkan landasan yang benar dan hanya Firman Tuhanlah yang menjadi panduan bagi orang tua untuk mendidik anak. Anak adalah makhluk yang sedang mengalami perkembangan. la belum mengetahui norma-norma kesusilaan, yang baik dan yang buruk. Hidupnya masih dikuasai oleh keinginan dari pikirannya. Oleh sebab itu, anak perlu diarahkan agar pikiran dan keinginannya tidak menyimpang dari kebenaran Firman Allah.

Banyak orang tua yang terlalu sibuk dengan pekerjaan diluar rumah dan kurang memperhatikan anaknya, ada juga orang tua yang over protektik terhadap anaknya sehingga ruang gerak anak terbatas. Disituasi yang lain, juga ditemukan orang tua yang terlalu banyak menyalahkan diri mereka sendiri untuk segala sesuatu yang dilakukan oleh anak mereka.

Dalam buku Gary Chapman mengajarkan tentang bahasa cinta anak-anak. Dengan mengenal bahasa cinta anak-anak dari orang tua mampu berhubungan dan mendidik anak dengan baik. Bila orang tua menggunakan kata-kata yang kasar dalam berkomunikasi, maka anak melawan pada orang tuanya. Perkataan orang tua akan diingat oleh anak, baik perkataan yang baik maupun perkataan yang buruk atau yang bersifat julukan yang mengejek. Segala sesuatu yang dilakukan oleh orang tua haruslah dilandaskan kepada kasih Kristus, baik itu kritikan maupun teguran. 


\section{Mendidik Dengan Kesehatian}

Orang tua harus mengetahui di mana wilayahnya dalam keluarga. Orang tua juga harus membagi tugas dalam mendidik anak. Orang tua harus memiliki program dalam keluarga, yaitu program-program yang sudah disepakati bersama. Program-program yang sudah dibuat harus dapat berjalan secara terus menerus, bukan hanya sesekali saja. Seorang ayah yang mempunyai cara pendidikan yang berbeda dengan ibu, akan menimbulkan konflik, yang kemudian berkembang menjadi Self Defeating Power atau kekuatan yang saling melemahkan. Apabila anak melihat ada dualism dalam didikan dari orang tua baik ayah maupun ibu, maka ia akan mencari sesuatu untuk bisa di peralat dan hal ini adalah hal yang berbahaya. Anak yang sedang bertumbuh menjadi besar dan mulai menilai akan segera melihat adanya dualism, dengan demikian orang tua akan melemahkan pendidikan terhadap anaknya sendiri.

Berkaitan dengan hal di atas, perbedaan pendapat antar orang tua bukanlah sesuatu yang luar biasa. Namun jikalau perbedaan antara orang tua yang terus berlanjut, suatu ketika anak-anak mereka pasti akan mengetahui hal itu. Adanya ketidakserasian antara orang tua di rumah bagaimanapun juga akan membawa pengaruh pada perkembangan kepribadian anak. Anak akan menjadi bingung, perintah atau aturan mana yang harus diikuti. Ayah dan ibu haruslah sepaham dalam mendidik anak karena semakin kompak mereka dalam mendidik anak akan semakin baik. Mereka harus merundingkan semua peraturan rumah tangga. Dalam menjalankan disiplin pun mereka tidak boleh bertentangan.

\section{Mendidik dengan Kekonsistenan}

Kekonsistenan secara singkat didefinisikan sebagai keberaturan dan keadaan yang dapat diduga. Seorang ayah yang berhasil konsisten dalam pribadi dan tindakannya adalah seorang ayah yang menguasai suasana hatinya. la tidak menunjukkan kasih sayang dalam satu menit dan kemarahan dalam satu menit berikutnya. Seorang ayah yang konsisten juga menguasai tingkah lakunya. Pada dasarnya hal itu berarti bahwa anak-anaknya dapat bergantung pada sikapnya yang selalu menjadi ayah mereka. Orang tua yang konsisten adalah figur yang dapat di pegang janjinya.

Ken R. Canfiel menuliskan dalam bukunya:

Seorang ayah yang berhasil tidak membuat janji yang tidak dapat dipegangnya dan janji yang dibuatnya dipenuhinya. la juga mempraktikkan apa yang dikhotbahkannya dengan bersikap konsisten dalam tingkah laku dan moralnya. la tidak berkata satu hal mengerjakan yang lainnya. la menghindari kemunafikan berapapun harganya.

Seorang anak belajar melalui teladan dari orang tuanya. Mereka senantiasa mengambil tindakan-tindakan dan gaya hidup dari orang tuanya. Jika apa yang dikatakan tidak konsisten dengan apa yang diperbuat, merekalah yang pertama-tama melihatnya dan mengatakannya kepada orang tua. Ada yang mengatakan bahwa anak laki-laki sampai umur lima belas tahun berbuat apa yang dikatakan ayahnya, setelah itu ia berbuat apa yang diperbuat oleh ayahnya.

\section{E. Problematika Anak Usia 5-12 Tahun Yang Mengalami Krisis Kasih Sayang}

Pada bagian ini, penulis menguraikan problematika yang dialami oleh anak-anak usia 5-12 tahun yang mengalami krisis kasih sayang. Kondisi anak yang mengalami krisis 
kasih sayang bersifat perampasan kemerdekaan pribadi dan dalam hubungannya tehadap lingkungan sosial, hubungan dengan keluarga, dan hubungan dengan diri sendiri.

\section{Dalam Hubungan Dengan Sosial}

Manusia merupakan makhluk sosial yang harus berinteraksi dengan orang lain. Sebagai makhluk sosial, manusia tidak dapat hidup sendiri tanpa kehadiran orang lain atau sesamanya. Oleh karena itu, manusia saling memiliki ketergantungan satu dengan yang lain dan manusia memerlukan kemampuan berinteraksi dengan sesamanya. Menurut Hendropuspito dalam bukunya sosiologi sistematika mengatakan bahwa:

Masyarakat adalah suatu jalinan kelompok-kelompok sosial yang saling berkaitan dalam kesatuan yang lebih besar, berdasarkan kebudayaan-kebidayaan yang ada. Kelompok-kelompok yang ada dalam masyrakat tidak hidup sendiri-sendiri, melainkan saling membutuhkan. Kelompok-kelompok itu hanya dapat hidup karena adanya kesadaran akan perlunya kerjasama untuk saling memberi dan saling melengkapi kebutuhan manusia.

Selanjutnya Hendropuspito menyatakan bahwa masyarakat merupakan kesatuan terbesar dari manusia-manusia yang saling bekerja sama untuk memenuhi kebutuhan bersama atas dasar kebudayaan yang sama. Manusia bertanggung jawab sosial dalam kehidupannya di tengah-tengah masyarakat. Salah satu tanggung jawab sosial manusia sebagai umat Kristen perlu memiliki kepekaan untuk dapat peduli pada masalah sosial yang sedang dihadapi oleh masyarakat, terutama mereka yang tidak diperlakukan dengan tidak adil.

Oleh karena kurangnya kasih sayang dari orang tua kepada anak mengakibatkan sosial anak menjadi rusak, hubungan anak atau keluarga dengan masyarakat tidak baik. Dalam bagian ini penulis akan membahas masalah-masalah yang dihadapi anak.

\section{Keras Kepala}

Sikap keras atau keras kepala merupakan suatu sifat yang tidak mau berubah, meskipun sudah mendapat teguran dan peringatan berulang-ulang. Rainer menuliskan dalam bukunya yang berjudul "Mengendalikan Perilaku Anak", bahwa perilaku anak dapat digambarkan dalam tiga dimensi yaitu frekuensi, intensitas perilaku anak dan lama berlangsungnya perilaku anak. Ketiga hal tersebut akan menunjukkan sikap dan sikap asli anak, secara khusus anak yang keras kepala akan terlihat dari ketiga hal tersebut.

Jika hal ini dibiarkan, maka sikap keras anak dapat saja menyakiti hati orangorang yang ada disekitar mereka. Orang tua dan anak seringkali terlibat dalam konflik oleh karena sikap keras anak, dan sikap inilah yang terkadang membuat orang tua lebih memilih untuk membiarkan anak meraka melakukan keinginannya. Anak-anak sering memakai cara yang tidak lazim dalam melawan orang tua, yaitu dengan melakukan hal-hal yang tidak disukai oleh orang tua mereka.

Beberapa anak memiliki kepribadian yang keras, bahkan hampir tidak ada seorangpun yang disegani atau ditakuti. Berdasarkan kesaksian beberapa orang tua mengatakan bahwa anak-anak kurang memiliki sikap sikap hormat kepada orang tua mereka sehingga nasihat dan teguran orang tua diabaikan begitu saja apabila tidak sesuai dengan keinginan dan hatinya. Hal ini disebabkan karena orang tua kurang 
memberikan kasih sayang atau waktu yang khusus bagi anak-anak sehingga anak-anak tidak mempunyai seseorang untuk ditakuti dan dihormati.

\section{Suka Berkelahi}

Anak yang tidak mendapat perhatian atau kasih sayang dari orang tua, keluarga, atau lingkungan maka sikap anak tidak akan baik dalam pertumbuhannya. Karena hidupnya tidak ada dididik atau dibimbing dari orang-orang yang seharusnya memberikan perhatian. Anak yang suka berantam sebenarnya bukan keinginan mereka, tetapi karena mereka ingin mencari perhatian dari orang-orang sekitar, dan dalam hubungan dengan sosial orang tua harus mengajarkan kepada anaknya untuk dapat menjalin hubungan yang baik dan menjadi anak yang membanggakan.

Maka dari itu, sebagai orang tua atau guru harus dapat memberikan kasih sayang ketika melihat anak yang berantam atau yang suka membuat keributan di sekolah harus diingatkan atau diberi perhatian khusus supaya menjadi anak yang baik.

\section{Dalam Hubungan Dengan Keluarga}

Bagi orang Kristen, keluarga adalah model dasar dari masyarakat. Peran keluarga atau orang tua sangat penting di dalam memberikan pertolongan kepada anak. Hal ini sangat membantu anak untuk memiliki perasaan diterima dan memperoleh dukungan dari keluarga yang adalah orang-orang terdekatnya. kedisiplinan adalah hal yang harus di ajarkan kepada anak sejak dini. Anak akan menjadi disiplin dengan sendirinya apabila dari sejak kecil sudah tertanam kedisiplinan dari orang tua atau tidaknya anak melihat teladan disiplin yang diberikan oleh orang tua. Disiplin dapat diajarkan melalui berbagai cara, disiplin juga tidak selalu harus keras dan menghukum. Disiplin berkaitan dengan ketegasan dan kekonsistenan orang tua dalam berbagai hal.

Orang tua harus memperkenalkan disiplin dan pengendalian diri kepada anak mereka dengan menggunakan pengaruh-pengaruh dari luar pada waktu anak masih kecil. Karena anak di tuntut agar bertingkah laku penuh tanggung jawab, maka anak akan mendapat pengalaman yang berharga dalam hal mengendalikan dorongan dan segala yang ada dalam dirinya. Hal inilah yang seharusnya mendorong orang tua untuk mengajarkan kedisiplinan kepada anak. Namun pada kenyataannya masih banyak orang tua yang kurang memahami hal ini, sama seperti orang tua di sekolah Sukacita. Para orang tua kurang memahami hal kedisiplinan, sehingga salah menerapkan disiplin kepada anak, dan yang sering dilakukan oleh orang tua adalah memarahi dan menghukum anak dengan memukul apabila anak melakukan kesalahan. Sementara yang lainnya justru banyak yang membiarkan anak melakukan kesalahan, tanpa memberitahukan kebenaran. Hal ini menunjukkan bahwa orang tua tidak menjalankan disiplin dalam keluarga.

\section{Dalam Hubungan Dengan Diri Sendiri}

Setiap orang yang hidupnya diawasi, diabatasi dalam bergerak dan ditempatkan dilingkungan yang tidak membawa perubahan yang baik tetapi menjadi lebih buruk, setiap anak mau supaya mendapat kasih sayang, perhatian dari keluarga terutama dari orang tua. Anak-anak yang mengalami krisis kasih sayang dari orang tua akan mengalami mengalami ketakutan, kecemasan, stress. Setiap orang memiliki ketakutan dalam hidupnya pada saat menghadapi persoalan yang harus diselesaikan, rasa takut terhadap orang, tempat, situasi atau benda tertentu. 
Menurut pendapat dari salah satu guru bahwa ada beberapa anak yang sering sendiri dan tidak banyak bergaul dengan yang lain atau dengan teman-temannya. Hal ini juga dialami oleh seorang siswa yang bernama Q.P (Nama Inisial) juga kurang bergaul dengan teman-temannya di sekolah. Ketakutan yang dialami oleh anak-anak ialah karena kurangnya kasih sayang atau waktu yang orang tua berikan bagi anakanak. Setiap orang pasti pernah mengalami kecemasan dalam hidupnya. Tingkat kecemasan terhadap suatu masalah berbeda-beda. Semuanya bergantung pada apa yang sedang dialami. Kecemasan merupakan perasaan kuatir, cemas, gelisah, dan rasa takut. Kennet Hambly seorang ahli psikologi menyatakan kecemasan itu adalah reaksi normal terhadap situasi yang menimbulkan stress. Apabila tingkat kecemasan meningkat, maka tingkat stress juga meningkat.

\section{F. Faktor Penyebab}

1. Kerohanian Anak yang Rendah

Istilah "kerohanian" memiliki pengertian sifat-sifat rohani, hal tentang rohani. Hal inilah yang dialami oleh K.A (Nama Inisial) yang dididik di bangku SMP mengalami hidup yang berbeda, dia memiliki pemahaman yang sangat terbatas tentang pengenalan akan Firman Tuhan. Hal ini diakibatkan oleh karena anaknya tidak aktif dalam mengikuti kegiatan-kegiatan ibadah atau kegiatan-kegiatan di sekolah tidak sungguh-sungguh dia ikuti karena terpengaruhnya dengan teman-temannya atau lingkungannya.

Dalam dituasi yang demikian, anak ini mudah terpancing oleh emosi. Seharusnya didalam keluarga orang tua harus lebih memperhatikan anaknya dan mengarahkan anaknya untuk mengikuti kegiatan-kegiatan di gereja maupun di sekolah supaya hidupnya menjadi lebih baik tidak kekurangan kasih sayang.

\section{Ekonomi}

Hal yang dimaksud dengan istilah ekonomi disini adalah tata kehidupan perekonomian, pemanfaatan uang, tenaga, waktu, seperti jurusan keuangan rumah tangga. Perekonomian sering sekali menjadi perkara besar dalam sebuah keluarga. Memang, bagi mereka yang memiliki keadaan ekonomi yang cukup, hal itu bukanlah menjadi masalah. Namun, bagi yang perekonomiannya rendah, hal ini adalah masalah yang sangat sulit untuk mereka atasi.

Berdasarkan hasil wawancara penulis, salah satu keluarga dari siswa sekolah Sukacita, kondisi ekonomi yang kuranglah yang menjadi penyebab anak menjadi kurang memiliki kasih sayang. Berdasarkan hasil wawancara penulis, salah seorang siswi sekolah sukacita yang bernama A putus berhenti sekolah karena diakibatkan perekonomian dalam keluarganya, A bekerja untuk menolong orang tua. Seharusnya anak seusia ini anak harus di perhatikan di dalam pendidikan supaya menjadi anak yang pintar, tetapi karena keadaan ekonomi tidak mendapat kasih sayang itu dari orang tuanya.

\section{Lingkungan Sosial}

Lingkungan adalah daerah (kawasan). Kondisi sekitar yang mempengaruhi perkembangan atau tingkah laku seseorang. Berkenaan dengan pernyataan di atas penulis memperoleh informasi dari pengakuan ibu $\mathrm{R}$ menjelaskan bahwa, seorang anak murid yang bernama A, dia tidak mendapat kasih sayang dari orang tua karena dia 
tinggal oleh ibunya dan sekarang dia tinggal bersama dengan ayahnya. Tetapi dari ayahnya pun dia tidak mendapat kasih sayang, dia meninggalkan sekolahnya karena terpengaruh dengan lingkungannya. Di lingkungan sekolah A ketahuan melihat film porno, guru berusaha untuk membimbing dia tetapi karena tekanan yang dia hadapi di keluarganya, dia tidak mendengarkan dan A memilih untuk berhenti sekolah.

Dari segi sosial, siswa/siswi juga ada yang memiliki jiwa sosial yang tinggi. Hal ini dapat terlihat dari keseharian mereka yang masih menjunjung tinggi kebiasaan untuk bergotong royong. Siswa/siswi mengambil bagian didalam berbagai kegiatan yang ada di sekolah Sukacita, terbukti dari sikap mereka yang saling tolong menolong dalam berbagai acara, baik acara Natal maupun acara Paskah. Lingkungan sosial yang baik akan memberikan pengaruh yang baik juga.

Dengan demikian, lingkungan sangat mempengaruhi keadaan atau pikiran anakanak, maka sebagai orang tua harus lebih memperhatikan anaknya supaya tidak terpengaruh dengan lingkungan sosial tidak baik.

Semua orang tua mengalami beragam problem dalam menghadapi anak-anak mereka, problem itu dapat muncul dari pribadi dan cara orang tua memberikan kasih sayang kepada anak-anaknya dan dari karakter anak itu sendiri. Kesalahan orang tua dalam menerapkan kasih sayang atau perhatian kepada anak akan berdampak pada perkembangan emosi sehingga muncul masalah-masalah emosi pada diri anak. Kehadiran orang tua sangat berpengaruh bagi perkembangan anak pada usia 5-12 tahun dan orang tua yang salah dalam memberikan kasih sayang maka anak tidak bertumbuh secara total.

\section{G. Penerapan Pastoral Konseling Terhadap Anak Usia 5-12 Tahun Yang Mengalami Krisis Kasih Sayang}

Pada dasarnya pastoral konseling adalah suatu proses yang dibuat untuk menolong konseli yang bermasalah. Konseling merupakan suatu proses situasi sementara yang bertujuan membangun terbentuknya relasi konselor dan konseli sehingga konseli dapat memahami dan mampu menghadapi permasalahannya sendiri. Proses konseling itu memiliki awal dan akhir, dapat dilakukan dalam beberapa pertemuan. Sebab pelaksanaannya membutuhkan waktu. Jadi tujuan pastoral konseling itu adalah untuk membawa seseorang pada pengenalan akan Allah melalui Firman-Nya. Selain itu juga pastoral konseling dapat menolong seseorang untuk mendapatkan solusi dari persoalan yang dihadapinya.

Selanjutnya penulis akan menguraikan pastoral konseling bagi anak usia 5-12 tahun yang mengalami krisis kasih sayang dan aplikasinya bagi anak-anak di sekolah Sukacita yang meliputi didalam tujuan dari pelayanan pastoral konseling dan pelayanan pastoral konseling bagi anak yang mengalami krisis kasih sayang, dampak pelayanan pastoral konseling, dan strategi pelayanan pastoral konseling.

\section{Tujuan Pelayanan Pastoral Konseling Bagi Anak Yang Mengalami Krisis Kasih Sayang}

Pelayanan pastoral merupakan pelayanan yang sangat penting dilakukan seorang guru bagi anak-anak usia 5-12 tahun yang mengalami krisis kasih sayang dari orang tua. Oleh karena banyak masalah yang terdapat dalam kehidupan anak-anak yang membutuhkan penyelesaian. Dalam bagian ini penulis akan menguraikan tujuan dari pelayanan pastoral konseling yaitu: anak yang mengalami krisis kasih sayang tidak 
dapat menunjukkan sikap anak yang berkepribadian baik, menjadi anak yang taat, kerohanian anak bertumbuh, menjadi anak yang rajin belajar.

\section{a. Anak Berkepribadian Baik}

Bila melihat situasi saat ini, banyak ditemukan kasus-kasus anak yang berkepribadian buruk. Kepribadian buruk adalah bentukan keadaan, keluarga, dan lingkungan. Anak yang berkepribadian buruk dapat berubah jika ditangani secara baik dan cepat. Anak adalah fokus utama yang harus dibina kepribadiannya, oleh karena pembinaan pada anak usia dini lebih mudah dibandingkan anak yang sudah menginjak remaja. Tingkah laku adalah suatu penampilan, manifestasi keluar maupun kedalam, yang merupakan fungsi ataupun ekspresi dari kepribadian sebagaimana halnya istilahistilah lainnya, kepribadian juga dirumuskan menurut ahli yang mendalami suatu bidang pengetahuan tertentu.

Jika berkepribadian baik anak sebagai tujuan yang akan dicapai oleh orang tua, maka orang tua perlu bekerja keras dan bekerja sama dalam membentuk kepribadian tersebut. Anak yang berkepribadian baik akan terlihat dari sifat, watak, atau karakternya dalam kehidupan sehari-hari.

\section{b. Menjadi Anak yang Taat}

Belajar untuk patuh yang paling sederhana adalah hidup menurut peraturan. Ketaatan mengakui perlunya belajar untuk hidup dibawah kekuasaan, atau otoritas. Hal yang sama berlaku bagi kehidupan keluarga. Orang tua tidak boleh memakai kekuasaan dan otoritasnya untuk maksud-maksud pementingan diri sendiri, melainkan digunakan untuk kepentingan anak-anak.

Oleh sebab itu, setiap keluarga harus memiliki peraturan dan anggota keluarga harus memegang yang dibuat. Kasih satu sama lain, keinginan untuk kesejahteraan masing-masing, dan kekawatiran akan akibat-akibanya yang memotivasi seorang untuk taat. Namun, ketaatan adalah sesuatu yang harus diajar, karena manusia tidak dilahirkan dengan gen patuh. Demikianlah halnya orang tua harus mengajar anak hidup taat. Anak juga harus diajar bahwa setiap perbuatan memiliki akibat, sehingga anak menyadari bahwa Tuhan telah memberikan otoritas, kepada orang tua untuk ditaati.

\section{c. Kerohanian Anak Bertumbuh}

Orang tua seharusnya tidak boleh lupa bahwa kemampuan intelek saja tidak akan mengarahkan pertumbuhan kepribadian anak, apalagi mengubah dan membaharuinya. Anak merupakan pribadi multidimensional yang memiliki aspek emosi, rohani, mental, kehendak, dan jasmani. Karena ia memiliki aspek rohani, kebutuhannya patut dipenuhi. Kehadiran Allah melalui Roh Kudus-Nya dalam kehidupan anak, tentunya akan menjawab pemenuhan kebutuhan rohani itu. Kebutuhan rohani terpenuhi jika anak memiliki relasi yang hidup dengan Allah melalui Yesus Kristus. Pada waktu anak dibimbing untuk membuka hatinya kepada Tuhan Yesus Kristus yang telah berkurban bagi pengampunan dosa-dosanya, sikap diperkuat oleh hormat kepada Tuhan dan Firman-Nya bertumbuh secara perlahan, yang diperkuat oleh pendidikan rohani yang diperolehnya. Pengalaman ini akan berdampak positif pada pertumbuhan dan perkembangan watak dan moral anak. 
Pemazmur dalam Perjanjian Lama mengatakan bahwa, "permulaan hikmat adalah takut akan Tuhan, semua orang yang melakukannya berakal budi" (Mazmur 111:10), kemudian dikemukakannya juga, "Tuhan senang kepada orang-orang yang takut akan Dia, kepada orang-orang yang berharap akan kasih setia-Nya (Mazmur 147:11). Penulis Amsal juga berulang kali memberi penegasan tentang hal ini. "takut akan Tuhan adalah permulaan pengetahuan" (1:7), "takut akan Tuhan membenci kejahatan" (18:3). Perjanjian Baru juga mengemukakan bahwa takut akan Tuhan mendorong orang untuk hidup kudus dan memelihara kesucian (2 Korintus 7:1).

Menyimak semua pernyataan di atas tampaklah betapa pentingnya keluarga menanamkan sikap takut akan Tuhan dalam diri anak. Sikap dan perilaku ini sangat berguna untuk menumbuhkan nilai kebajikan terhadap sesame dalam diri anak.

\section{d. Menjadi Anak yang Rajin Belajar}

Orang tua dan guru tentu mengharapkan anak-anak memperoleh hasil belajar yang baik. Setiap anak berbeda, demikian juga cara belajar mereka berbeda. Jadi sebagai orang tua atau guru memiliki metode yang berbeda dalam mengajar, melalui cara yang berbeda-beda mereka dapat memperluas lingkup belajar, menambah pengetahuan, membangkitkan minat, dan daya tarik belajar. Dengan cara yang berbeda dalam mengajar anak supaya menjadi anak yang rajin belajar, orang tua atau guru memiliki tujuan atau metode yang berbeda dalam mengajar dan melalui ini anakanak akan semakin bertambah pengetahuan mereka dan kepintaran mereka akan membuat perkembangan dan pertumbuhan bagi mereka.

\section{Metode Pastoral Konseling Terhadap Anak Yang Mengalami Krisis Kasih Sayang}

Metode pastoral konseling merupakan cara yang tepat untuk diapakai dalam membimbing sesuai dengan sistem yang ditentukan. Tujuannya untuk memudahkan pembimbing dalam mengarahkan yang dibimbing menemukan Allah dan jati dirinya. Pada bagian ini penulis akan memaparkan metode pastoral konseling dalam kerohanian yang tepat bagi anak usia 5-12 tahun yang mengalami krisis kasih sayang antara lain yaitu:

\section{a. Melalui Cerita Firman Tuhan}

Cerita merupakan bagian yang sangat disukai oleh anak-anak pada usia 5-12 tahun. Allah tahu bahwa manusia mudah belajar melalui cerita yang sekaligus dapat memberi pengetahuan, menyentuh perasaan, kemauan dan membangun perilaku yang baik. Jadi secara langsung Allah mengajarkan hal-hal yang bersifat rohani kepada manusia melalui kejadian sehari-hari dan semuanya itu diceriatkan dalam Alkitab.

Hal tersebut dapat dimanfaatkan oleh pastoral konseling dalam pembimbingan kerohanian anak pada usia 5-12 tahun. Karena anak-anak pada usia ini sangat cenderung dalam meniru. Selain itu anak-anak usia 5-12 tahun menyukai hal-hal yang menambah pengethuannya. Dalam bercerita ada dua bagian yang dapat menunjang perkembangan cara bercerita, antara lain dengan menggunakan alat peraga dan dengan menggunakan alat peraga yang lainnya.

\section{b. Melalui Pelayanan Pribadi}

Pelayanan pribadi yang dimaksud adalah pelayanan yang dilakukan oleh pembimbing kepada yang dibimbing secara empat mata. Pelayanan pribadi yang 
dilakukan membutuhkan kasih, perhatian, kepekaan, dorongan, kesabaran, dan kerendahan hati dengan selalu setia membimbing anak-anak. Dalam pelayanan pribadi ada target yang harus dicapai yaitu orang yang dibimbing dapat menyelesaikan masalah tersebut dibutuhkan pelayanan pastoral konseling.

Pelayanan pribadi memberikan kesempatan yang baik kepada anak-anak, agar anak-anak dapat mengutarakan seluruh isi hatinya secara terbuka kepada pembimbing. Sehingga anak-anak yang memiliki karakter buruk dapat diubahkan menjadi anak-anak yang memiliki karakter anak yang baik.

\section{c. Melalui Pujian}

Manusia diciptakan untuk memuji dan menyembah Allah. Jikalau manusia memuji dan menyembah Allah dengan benar, maka kebutuhan yang terutama dalam hidupnya akan terpenuhi. Sebab pujian dapat memberikan semangat, penghiburan, dan membuat beban dihati menjadi berkurang.

Anak-anak di usia 5-12 tahun memiliki sikap yang masih polos dan tidak dapat menahan perasaan mereka. Misalnya ketika mereka jatuh atau sedih pastinya mereka tidak dapat menahan hal tersebut, sehingga sikap mereka diekspresikan dengan menangis. Sedangkan ketika mereka bergembira akan mengekspresikan melalui pujian atau menyanyi dan tertawa. Dengan demikian pujian merupakan ekspresi diri anak yang mana mereka tunjukkan melalui nyanyian atau lagu.

\section{d. Melalui Permainan}

Permainan merupakan bagian yang sangat menarik dan menyenangkan. Bagi anak-anak usia 5-12 tahun permainan adalah bagian yang tidak dapat ditunda dan digantikan oleh apapun. Di mana anak-anak pada usia 5-12 tahun menyukai hal-hal yang baru dan menantang mereka untuk terus bergerak. Melalui permainan anak-anak dapat mengekspresikan perasaannya dengan bergerak bebas.

Dengan demikian, maka permainan anak-anak usia 5-12 tahun dapat mengekspresikan dirinya dengan bergerak bebas. Di mana kesempatan-kesempatan untuk mengikuti permainan bersama tidak hanya memberikan kesenangan dan kegembiraan tetapi juga membantu mengajarkan norma-norma hidup Kristen serta perilaku sosial. Namun pergerakan mereka pun terus diawasi agar mereka tidak mengalami cidera yang dapat membahayakan keselamatan.

\section{e. Melalui Doa}

Doa yang dimaksudkan adalah doa yang benar di mana anak-anak dapat secara terbuka mengungkapkan perasaa terdalam kepada Allah. Perasaan tersebut sebagai tanda, bahwa mereka mampu mengucap syukur. Melalui doa pembimbing dapat mengarahkan anak-anak yang dibimbing untuk mengalami kelegaan dari perasaan yang menekan mereka. Pembimbingan kerohanian yang dilakukan melalui doa akan membuat pembimbing kuat dan sabar dalam membimbing anak-anak. Membuat orang yang dibimbing merasakan kuasa Roh kudus dalam hatinya, sehingga ia dapat mengalami perubahan kapada karakter anak yang baik. 


\section{Dampak Pelayanan Pastoral Konseling Terhadap Anak Usia 5-12 Tahun Yang Mengalami Krisis Kasih Sayang}

Pembimbingan kerohanian yang diterapkan oleh guru yang mengajar di sekolah dan orang tua bagi anak-anak usia 5-12 tahun yang mengalami krisis kasih sayang akan memiliki dampak yang positif. Dampak pelayanan pastoral konseling bagi anak-anak yang mengalami krisis kasih sayang akan terlihat dari perubahan kepribadian anak di mana mereka akan mengalami pemulihan secara spiritual, psikologi, jasmani atau fisik dan sosial. Selain itu anak-anak yang mengalami krisis kasih sayang akan menemukan jati dirinya.

\section{a. Anak Mengalami Pemulihan}

Penebusan yang Allah nyatakan adalah melalui kematian Tuhan Yesus Kristus di kayu salib yang merupakan dasar utama bagi kehidupan manusia. Pada dasarnya manusia adalah makhluk ciptaan Allah yang sempurna, namun kesempurnaan itu menjadi cacat karena manusia jatuh kedalam dosa. Oleh sebab itu, yang dibutuhkan manusia adalah pemulihan. Pemulihan merupakan dampak yang terjadi dari proses pembimbingan kerohanian bagi anak-anak yang mengalami krisis kasih sayang, sehingga anak akan memiliki karakter yang baik. Berdasarkan hal tersebut pada bagian ini penulis akan memaparkan pemulihan yang akan terjadi bagi anak-anak usia 5-12 tahun yang mengalami krisis kasih sayang.

\section{b. Secara Spiritual}

Pada saat manusia jatuh kedalam dosa secara otomatis hubungan antara manusia dengan Allah menjadi rusak total. Oleh sebab itu anak-anak membutuhkan Juruselamat yang dapat menyelamatkan dan mendamaikan anak-anak dengan Allah yaitu dengan percaya kepada Tuhan Yesus Kristus sebagai Tuhan dan Juruselamat pribadi. Firman Tuhan menyatakan, "Akulah jalan kebenaran dan hidup. Tidak ada seorangpun yang datang kepada Bapa, kalau tidak melalui Aku” (Yohanes 14:6). Hal ini menjelaskan bahwa tidak akan ada seorang pun yang datang kepada Allah Bapa kalau tidak melalui Tuhan Yesus Kristus.

Anak-anak yang tidak hidup didalam Tuhan, secara spiritual tidak akan pernah memiliki hubungan yang baik dengan Allah. Karena mereka merasa bahwa Allah tidak pernah ada baginya bahkan mereka tidak pernah kenal. Oleh sebab itu anak-anak yang mengalami krisis kasih sayang dari orang tua harus mendapat pembimbingan kerohanian, agar mereka memperoleh keselamatan dan diperdamaikan dengan Allah melalui Tuhan Yesus Kristus. Setelah anak-anak yang mengalami krisis kasih sayang diselamatkan dan diperdamaikan dengan Allah, maka mereka akan menerima pemulihan secara spitual. Melalui pemulihan tersebut, maka anak-anak akan memperoleh janji Allah yaitu anak-anak akan mendapat bagian dalam RohNya (1 Yohanes 4:13), akan disebut anak Allah (1 Yohanes 3:1), dan akan dijadikan ahli waris dalam kerajaan sorga (Roma 8:17).

\section{c. Secara Jasmani dan Fisik}

Pembimbingan kerohanian yang diberikan oleh guru, dan orang tua kepada anakanak yang mengalami krisis kasih sayang dapat mempengaruhi perkembangan fisik anak tersebut. Karena keadaan fisik anak juga dipengaruhi oleh kondisi spiritual dan psikologinya. Firman Tuhan menyatakan bahwa, "Hati yang gembira adalah obat yang 
manjur, tetapi semangat yang patah mengeringkan tulang" (Amsal 17:22). Senada hal tersebut Yakub B. Susabda berpendapat, "Banyak sekali kejiwaan (misalnya perasaan tidak aman, sedih, marah, cemas) yang langsung dapat mempengaruhi kondisi tubuh". Hal ini menunjukkan bahwa spiritual dan psikologi memiliki pengaruh yang besar dalam proses pemulihan jasmani atau fisik bagi anak-anak yang mengalami krisis kasih sayang.

Dengan demikian, secara jasmani atau fisik anak-anak kurang kasih sayang juga mendapatkan bimbingan rohani mereka mengalami perkembangan yang baik, karena secara spiritual dan psikologi anak-anak sudah dipulihkan.

\section{d. Secara Sosial}

Anak-anak yang kurang kasih sayang atau kurang mendapat perhatian telah mengalami pemulihan secara spiritual, spikologi dan jasmani diharapkan dapat mengalami pemulihan secara sosial. Karena anak-anak telah menerima kasih Allah dalam hidupnya mereka akan dapat memberikan kasih tersebut kepada orang lain. Sebab Firman Tuhan menyatakan, "Barang siapa mengasihi Allah ia harus juga mengasihi (1 Yohanes 4:21b). Hal tersebut menjelaskan bahwa ketika anak-anak telah menerima kasih Allah, maka kasih tersebut akan dapat diterapkan pada orang lain. Dengan demikian, dampak pembimbingan kerohanian akan mempengaruhi kehidupan sosial anak-anak yang mengalami krisis kasih sayang.

\section{Strategi Pelayanan Pastoral Konseling Bagi Anak Yang Mengalami Krisis Kasih Sayang}

Dalam melayani atau membina anak-anak usia 5-12 tahun yang mengalami krisis kasih sayang dapat menggunakan banyak metode merupakan cara dalam menyampaikan materi pembinaan, agar dapat secara efektif dan efesien diterima oleh anak-anak dan dapat menghasilkan perubahan dalam diri anak, baik dalam perubahan dalam berfikir, bertindak atau tingkah laku. Dalam rangka memulihkan kepribadian anak perlu dilakukan strategi atau metode yang dilakukan sebagai berikut:

\section{a. Melalui Perkunjungan}

Istilah perkunjungan berasal dari kata dasar "kunjung" yang berarti pergi atau datang dengan tujuan untuk menemui dan menjumpai. Sedangkan kunjungan mempunyai arti proses, cara, atau perbuatan mengunjungi atau perlawatan. Dengan demikian, yang dimaksud dengan perkunjungan yaitu perbuatan yang dilakukan dengan pergi atau datang dengan tujuan untuk mengunjungi orang lain. Dengan berkunjung dapat mengenal satu demi satu orang yang dilayani dengan baik.

Perkunjungan seorang gembala kepada domba gembalaannya adalah tugas yang berprioritas tinggi, oleh karena gereja yang berhasil adalah gereja yang berkunjung. Kebanyakan pendeta atau atau guru setuju bahwa kunjungan adalah salah satu tugas seorang gembala atau seorang guru yang berprioritas tinggi. Kontak dengan keluarga siswa/siswi harus memiliki hubungan yang erat dengan guru yang mengajar. Memelihara, memberitakan, dan memimpin. Ketiga pelayanan tersebut dipelancar, bila berkenalan baik dengan orang-orang yang digembalakan dan dipimpin dengan orang mendengar Firman Tuhan yang diberitakan.

Seperti Yesus Kristus yang selalu setia mengunjungi domba-domba-Nya yang sakit, lemah dan bermasalah. Demikian juga dengan gembala harus setia dengan 
jemaatnya dan begitu juga dengan guru harus lebih setia dan memiliki kekreaktifan dalam mengunjungi siswa/siswi nya. Perkunjungan pastoral merupakan alat dalam pelaksanaan penggembalaan jemaat. Dengan demikian, kedatangan seorang guru atau orang tua akan sangat menolong anak-anak usia 5-12 tahun yang mengalami krisis kasih sayang dari dalam keluarga. Melakukan kunjungan kepada siswa/siswi dapat mengarahkan siswa/siswi sehingga tahu bagaimana cara memberikan kasih sayang kepada anak-anaknya dan harus mencari pertolongan dan bantuan untuk dapat mengatasi masalah yang dihadapi dalam keluarga. Perkunjungan pastoral konseling bermaksud untuk memberi perhatian khusus kepada siswa/siswi yang mengalami krisis kasih sayang dari keluarga.

\section{b. Melalui Pengajaran di Sekolah}

Dalam pastoral konseling harus memiliki pengajaran yang benar, secara khusus pengajaran itu harus sesuai dengan Alkitab. Dalam Firman-Nya didalam Kitab Amsal menjelaskan tentang pendidikan kepada anak, dan anak akan mendapat pendidikan itu dari orang tua jika didalam rumah, tetapi didalam sekolah anak akan mendapat pendidikan itu dari guru yang mengajar dan sebagai guru harus bertanggung jawab untuk memberikan pengajaran yang benar. Dengan demikian hasil dari penelitian penulis didalam sekolah Sukacita melihat adanya semangat guru dalam mengajar siswa/siswi dan anak-anak yang dididik mendapat kasih sayang atau perhatian dari gurunya melalui pengajaran dan melalui pelayanan yang lainnya.

\section{c. Melalui Pelayanan Pribadi}

Pelayanan pribadi, sesungguhnya adalah pola pelayanan Allah bagi manusia sejak semula. Ketika manusia jatuh ke dalam dosa dan mengalami kehancuran di dalam hidupnya; Allah datang dan melayani mereka secara pribadi. Dalam pelayanan pribadi yang paling prinsip adalah dapat memperkenalkan Tuhan Yesus sebagai Juruselamat pribadi dan penebus dosa, tetapi juga memperoleh anugerah pengampunan dosa dan diperdamaikan dengan Allah serta mulai hidup baru. Disamping itu pelayanan pribadi juga sangat efektif dalam menggembalakan seseorang di dalam perkembangan imannya. Pelayanan pribadi tidak cukup dilakukan sekali saja, harus dilanjutkan tahap demi tahap sesuai dengan kebutuhan dan perkembangan iman petobat sampai yang bersangkutan siap melayani Tuhan (Matius 28:19-20). Pelayanan pribadi harus memandang kepada Allah sebagai teladan yang patut diteladani dalam pelayanan umat-Nya.

Dengan demikian, pelayanan pribadi merupakan pelayanan yang telah Allah lakukan terhadap manusia yang telah berbuat dosa. Pelayanan pribadi haruslah mempunyai arah yang jelas yaitu memperkenalkan Yesus Kristus sebagai Tuhan. Tujuan dari pada pelayanan pribadi sangat jelas, menuntun orang pada pertobatan supaya manusia dapat menerima Tuhan Yesus Kristus, begitu juga dalam melayani anak-anak yang mengalami krisis kasih sayang dari orang tua melalui pelayanan pribadi dapat ditolong dan dilepaskan dari masalah yang dialami. Dimana dalam pelayanan pribadi terhadap anak usia 5-12 tahun yang mengalami krisis kasih sayang dapat dibina dan dibimbing dalam memahami Firman Tuhan, sehingga dapat menerima Tuhan Yesus Kristus dan Juruselamat pribadinya. 


\section{d. Melalui Pembimbingan}

Bimbingan adalah unsur yang paling penting dalam pengalaman orang Kristen. Roh Kudus adalah pembimbing orang Kristen. Bimbingan sangat dekat relasinya dengan pengajaran. Pendapat $H$. Faber tentang tugas penggembalaan, yaitu "menolong orang satu persatu untuk menyadari hubungannya dengan Allah, dan mengajar orang untuk menyatakan ketaatan kepada Allah dan sesama. Memberikan bimbingan kepada anak-anak usia 5-12 tahun, secara Alkitabiah berarti bimbingan yang sifatnya pengajaran maupun penggembalaan.

Hanya orang yang dipenuhi oleh Roh Kuduslah yang dapat dibimbing dengan efektif untuk mengenal kehendak Allah dan berjalan dalam kehendak Allah. Orang yang dipenuhi atau dikuasai oleh Roh Kudus dapat menaklukkan diri (taat) kepada Firman Allah. Jadi, bimbingan merupakan pengajaran yang diberikan kepada orang yang membutuhkan pertolongan untuk dapat mengerti dan memahami persoalannya. Jika pelayanan pastoral ini diterapkan kepada guru atau orang tua murid Sukacita, maka jelas bahwa bimbingan yang diberikan terutama untuk membawa anak-anak datang kepada Allah dan mengajar mereka bagaimana hidup takut akan Tuhan serta menjadi berkat bagi orang lain.

\section{Kesimpulan}

Pastoral konseling merupakan salah satu alat yang dipakai oleh Allah untuk membawa manusia mengalami pertobatan dan pembaharuan dalam hidupnya. Pelayanan pastoral juga merupakan usaha dari orang tua atau guru yang mengajar disekolah dengan cara memberikan perhatian, kasih sayang, melalui perkunjungan, pengajaran disekolah, pelayanan pribadi dan pembimbingan. Dengan demikian pelayanan pastoral konseling sangat penting dilakukan bagi anak usia 5-12 tahun yang mengalami krisis kasih sayang. Allah dapat memakai pelayanan pastoral konseling untuk menolong mereka dan menuntun mereka mengalami pertumbuhan kerohanian, sekaligus menuntun mereka untuk menerima Kristus secara pribadi. Pastoral konseling ini dapat dilakukan melalui perkunjungan ke rumah anak-anak supaya melalui perkunjungan hamba Tuhan dapat mengetahui secara langsung keadaan anak yang mengalami krisis kasih sayang.

Selain itu guru juga dapat mengadakan pelayanan pribadi, melalui Firman Tuhan yang didengar di sekolah, sehingga anak mengambil komitmen untuk dapat menerima Tuhan Yesus sebagai Tuhan dan Juruselamat pribadi, mendapatkan pemahaman yang benar akan kehendak Tuhan, mengetahui kewajiban yang seharusnya dilakukan oleh anak terhadap orang tuanya. 


\section{Kepustakaan}

Abineno, J. L. CH., 2000

Adams, Jay E., 2000

Baker Keneth, 1997

Boyd, Charles F., 2006

Canfiel, Ken R., 1992

Chapman Gary, 2000

Clinebell, Howard, 2002

Hendropuspito, D., 1989

Dobson, James, 1995 1996

Dodson, Fitzhugh, 1991

Douglas, J. D., 1997

Ingouf, E. Hon, 1988

Freese, Doris A., 1993

Gunarsa, Singgih D., 1976

1978

1987

1989

1998

Harris, Laird, 1981
Pedoman Praktis Untuk Pelayanan Pastoral, Jakarta: Gunung Mulia Masalah-Masalah Dalam Rumah Tangga Kristen, Jakarta: BPK Gunung Mulia

The New Brow Briggs Hebrew and Lexicon, Massachusetts Hendrikson Publishers

Menyikapi Perilaku Anak Sesuai Dengan Karakter, Bandung: Yayasan Kalam Hidup

7 Rahasia Menjadi Ayang Yang Efektif, Yogyakarta: ANDI

Lima Tanda Keluarga Yang Mantap, Batam: Interaksara

Tipe-Tipe Dasar Pendampingan dan Konseling Pastoral, Yogyakarta: Gunung Mulia

Sosiologi Sistematika, Yogyakarta: Kanisius, 1989

Masalah Membesarkan Anak, Bandung: Yayasan Kalam Hidup

Menjadi Orang Tua Bukan Untuk Orang-Orang Pengecut, Jakarta:

Departemen Penerbitan I.H.O

Mendisiplin Anak Dengan Kasih Sayang, Jakarta: BPK Gunung Mulia

Ensiklopedi Alkitab Masa Kini Jilid I, Jakarta: Yayasan Komunikasi Bina Kasih/OMF

Sekelumit Tentang Gembala Sidang, Bandung: Lembaga Literatur Baptis

Pekan Pendidikan Anak-Anak, Malang: Gandum Mas

Psikologi Untuk Keluarga, Jakarta: BPK Gunung Mulia

Psikologi Perkembangan, Jakarta: BPK Gunung Mulia, Psikologi Untuk Membimbing, Jakarta: BPK Gunung Mulia

Psikologi Perawatan, Jakarta: BPK Gunung Mulia

Dasar dan Teori Pertumbuhan Anak, Jakarta: BPK Gunung Mulia

Theological Wordbook of The Old Testament, Chinago: Moody Press 
Jacobsen, Margaret Baliley,

1996 Ketika Anak Akan Bertumbuh, Bandung: Kalam Hidup

Kilbourn, Phillips, 2002

Anak-Anak dalam Krisis, Batu: YPPII-Dep. PAP

Leigh, Ronald W., 1988 Melayani Dengan Efektif, Jakarta: BPK Gunung Mulia

Lumintang, Stevri I., 2010 Keunikan Theologia Kristen, Batu: Departemen Literatur PPII

Mirer, Paul D., 2009 Pengantar Psikologi dan Konseling Krisis, Yogyakarta: Andi

Moeliono, Anton M., 1988 Kamus Besar Bahasa Indonesia. Jakarta: Balai Pustaka 1995 Kamus Besar Bahasa Indonesia Edisi Kedua, Jakarta: Balai Pustaka Mossholder, Ray, 1998 Cara Mendidik Anak di Tengah Lingkungan Yang Makin Sekular, Yogyakarta: ANDI

Panjaitan, Fermin, 1983 Pelayanan Pribadi Praktis Mengenai Pertobatan, Jakarta: BPK

Salim, Peter, $1991 \quad$ Kamus Bahasa Indonesia Kontemporer, Jakarta: English Press

Saputra U.T., $2004 \quad$ Iman di Tengah Masyarakat, Bandung: Bina Media Informasi Scheunemann, Volkhard, 1988 Apa Kata Alkitab Tentang Dogma Kristen, Malang: YPPII

Schneider, Gerhard, 1993 Exegetical Dictionari of the New Testament, Michigan: Berdmans Publishing Company

Simanjuntak, Julianto 2007,

Mendidik Anak Sesuai Zaman dan Kemampuannya, Tangerang: LK3 Gunung Mulia

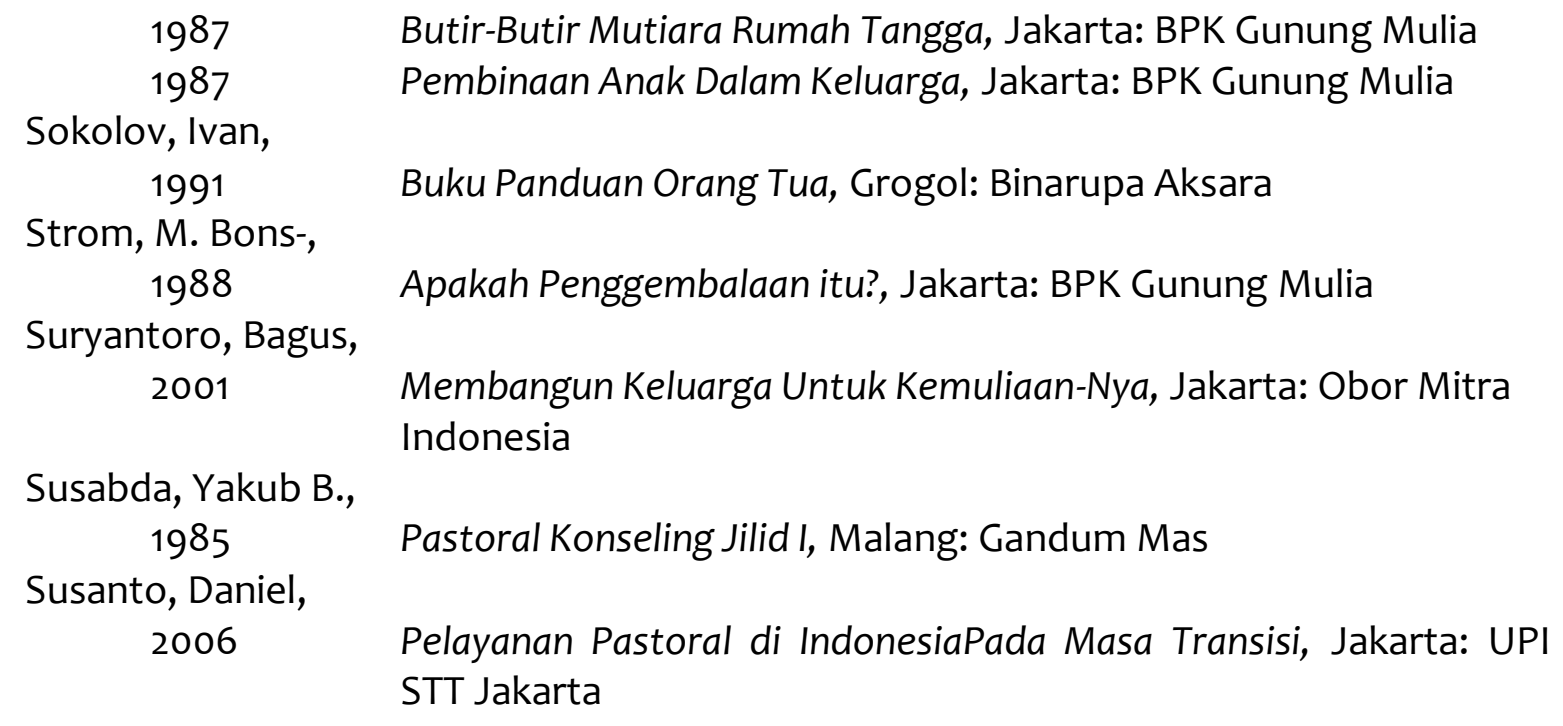
1987 
Tong, Stephen,

1991 Membesarkan Anak Dalam Tuhan, Jakarta: Lembaga Reformed Injil Indonesia

Tu'u, Tulus,

2010 Dasar-Dasal Konseling Pastoral, Yogyakarta: ANDI

Wuisan, Antonius,

1994 Konseling Suatu Pendekatan Pemecahan Masalah, Jakarta: Gunung Mulia

Internet :

- Html http://eostudent. Blogspot. Com/2013/12/laporan-observasi-kenakalansiswa, Online 27 Oktober 2014

- Http://sentuhhikmat.blogspot.com/2010/07/mengatasi-tekanan-

batin.html\#.PDoUCFImpHE 